\title{
Conclusion - The Consolidation of Democracy versus Democratization in Turkey
}

\section{Metin Heper}

To cite this article: Metin Heper (2002) Conclusion - The Consolidation of Democracy versus Democratization in Turkey, Turkish Studies, 3:1, 138-146, DOI: 10.1080/714005698

To link to this article: https://doi.org/10.1080/714005698

$$
\text { Published online: } 08 \text { Sep } 2010 .
$$

Submit your article to this journal $₫$

Цlll Article views: 451

Citing articles: 6 View citing articles 


\title{
CONCLUSION \\ The Consolidation of Democracy versus Democratization in Turkey
}

\author{
METİN HEPER
}

Democratization is attaining greater political participation. The consolidation of democracy is democracy becoming "the only game in town." The preceding contributions indicate that in recent years Turkey has made good progress in preparing the ground for consolidating its democracy. On the other hand, the country's success in democratizing its political regime has been less than adequate. It may sound paradoxical, but at least in the case of some political parties inadequate democratisation seems to have been functional for the progress Turkey has registered towards the consolidation of its democracy

The first prerequisite for the consolidation of democracy is a consensus among the members of the political class on the rules of democracyfreedom of expression, absence of restrictions on political participation, free and fair elections, and the like. Second, there must be national unity; political actors must act in unison when democracy faces a critical threat. For them to act in such a manner there would be need for trust and harmony among political actors.

For the consolidation of democracy in Turkey, political actors' acting in a responsible as well as responsive manner is also an important prerequisite. This means paying attention to the long-term interests of the country. In Turkey, the interests in question are those defined as critical by the military, since the 1982 Constitution and other relevant legislation has saddled the military with the task of protecting the county from internal as well as external threats. During recent years, the military has perceived the Kurdish question and political Islam as two critical internal threats.

The military fulfils its task of protecting Turkey from the internal as well as external threats via the National Security Council (Milli Güvenlik Kurulu-MGK). The MGK is made up of the prime minister, the deputy prime minister, the ministers of defense, interior, justice, and foreign 
affairs, the chief of the general staff, and four force commanders, and is chaired by the President of the Republic. According to the Constitution, the Council of Ministers must assess the recommendations made by the MGK. For this reason, if politicians do not pay adequate attention to the said interests not only do their parties lose political support (as was the case in the 1999 national elections), but the political regime itself also faces a crisis of legitimacy. In the past, such crises of legitimacy have thrice resulted in military interventions (1960-61, 1971-73, and 1980-83). More recently (1997), when the military again perceived an internal threat to the secular-democratic state, declined to take power into its own hands, and instead initiated a process that led to the non-voluntary resignation of the Prime Minister.

It is important to understand exactly what happened in this instance. Upon the insistence of its military members, the MGK recommended that the government adopt a number of measures against political Islam. The coalition government of the religiously-oriented Welfare Party (Refah Partisi-RP) and the secularly-oriented True Path Party (Doğru Yol Partisi-DYP) led by Necmettin Erbakan was not willing to adopt some of the measures recommended by the MGK, and only adopted condensed versions of others. Consequently, the military increased its pressure on the government. The military successfully mobilized the judiciary, universities, some civil societal associations as well as the people at large against the government. Afraid that the military might intervene, Erbakan resigned.

Until the 1980s the military wished to see "rational democracy" in Turkey, where political actors primarily seek what is best for the country through intelligent and patriotic debate, i.e., act responsibly. They do not solely pursue special interests through adversarial politics, i.e., act responsively. Since the early 1980s, the military increasingly softened their approach to democracy. Officers now grant that in democratic regimes politicians are expected to act responsively to particularistic interests. However, as noted, they continue to be rather sensitive on the issues of the Kurdish problem and political Islam. Also, since they still prefer intelligent and patriotic debate with a view to find out what is best to the country, they wish to see politics focused on policy issues rather than on politics, that is, on activities to capture and maintain power. Officers also want political actors to value merit over and above blind political loyalty. When political actors do not measure up to their expectations the military is disturbed and tempted to interfere in politics. It is patent that democracy cannot be consolidated in Turkey if the military continues to act in this manner. 
Does all this mean that it will never be possible to consolidate liberal democracy in Turkey? The opening sentences of this conclusion must have made it clear that the present author does see light at the end of the tunnel. For one thing, whenever the military in Turkey intervened, officers did not intend holding power indefinitely; they only wished to "save democracy from itself" and re-install "a more rationally functioning democracy." However, as noted, they have gradually come to the conclusion that "rational democracy" is a utopia. More significantly, the military realized that politics could not be successfully restructured by their interventions. The military now believes that its interventions adversely affect morale in the ranks; when the military takes power into its own hands the line of promotions are distorted and, soon after every intervention, the military faces the danger of losing prestige in the eyes of the people. Consequently, the military prefers not to intervene if it can help it. As noted, over the years, what the military has expected from the political actors has become less and less. Given Turkey's aspirations to become a full member of the European Union, in all probability, those expectations will decrease further in the near future. However, presently they are there and the consolidation of democracy in Turkey continues to depend upon their reasonable fulfillment by political actors.

Turning now to the problem of democratisation, here it is necessary to emphasize the fact that democracy in Turkey was introduced in the 1940s by state elites (read "politicians, bureaucrats, and officers who considered themselves as the only guardians of the long-term interests of the country") rather than by political elites that represented socio-economic groups. Being subscribers to "rational democracy," by making a transition to democracy the state elites aimed to expand the scope of the intelligent debate to find out what was best for the country. Consequently, the immediate goal of the introduction of democracy was not informed by a concern to expand political participation. In any case, as socio-economic groups had not played a significant role in the transition to democracy, there were no effective demands for increased political participation.

As a result, for a long time democracy in Turkey developed as a conflict between the state elites and political elites. The state elites tended to act basically as the guardians of the long-term interests of the country and held a condescending attitude towards the particularistic interests; political elites in turn perceived themselves primarily as the defenders of the particularistic interests. The state elites' expectations of democracy and the consequent rift between them and the political elites came to have critical implications for Turkish politics. 
For one thing, politics in Turkey tended to revolve around "high politics" rather than the day-to-day needs of the county and its people. Democracy and secularism became far more important problems than economic policy, environmental policy, foreign policy, and the like. In comparison to the latter problems, the former were more difficult to resolve, resulting in considerable tension in politics and, therefore, in the absence of harmony. Under the circumstances, political leaders were seen as heroes defending their parties against their adversaries, which gave them extensive leverage over the rank and file in their political parties. This state of affairs was an impediment to the development of intra-party democracy which was also made difficult because, as mentioned, the primary preoccupation was with "politics" rather than policy. This meant that those who aspired to powerful positions could not show their mettle in policy debates. If they challenged the leader on issues relating to "high politics" or, worse still, on a personal basis, they were summarily discharged from their parties.

The second important implication of the rift between the state elites and political elites had been the salience of political patronage and clientelism in Turkish politics. Being defenders of only particularistic interests with little regard to the long-term interests of the country seems to have created a tendency to attend to the specific needs of the people at the expense of the wellbeing of the economy as a whole. This tendency was reinforced by political patronage demands from the party rank and file. In the absence of an opportunity to shine in politics through their contribution to policymaking, the latter could only survive in politics if they managed to satisfy their constituents by fulfilling some specific services.

The third important implication of the ongoing rift between the state elites and political elites was that because the former perceived democracy as an end - that of finding what was best for the country-and not as a means - that of promoting the interests of social groups - democracy itself was not seen as the guilty party. That is, whenever the military intervened, they blamed the politicians, but not democracy. It was for this reason that the military did not consider staying in power indefinitely. Here the Turkish case differed significantly from the events in Europe between the World Wars. In the latter context, the workers were seen as a threat to bourgeoisie interests and, as a consequence, several countries drifted towards authoritarian regimes that lasted far longer than the military regimes in Turkey. The European authoritarian regimes, in contrast to the military regimes in Turkey, faulted democracy, and not politicians. In contrast, even in the single-party period in Turkey (1923-45) democracy 
became the ultimate, if not the immediate, goal. It was for that reason that the single-party - the Republican Peoples Party - itself introduced a multiparty regime, and the military continuously gave power back to the politicians.

Yet, as noted, perceiving democracy as an end and not as a means was a mixed blessing. In Turkey, democracy did become the only game in town, but the rules of that game did not resemble the rules of liberal democracy. In the Turkish case the military continued to assume the role of final arbiter. Consequently, although in recent years Turkey has taken important steps towards consolidating its democracy, it failed to completely democratize its political regime.

Thus, it is not surprising that the preceding contributions in this volume focus on this very dilemma in Turkish politics. Let me now turn to some observations made in these contributions that makes one think that Turkey has made good progress towards consolidating its democracy in recent years. The gist of the analyses contained in the said contributions is that in recent years three government and three opposition parties (out of seven political parties in Turkey) have in different degrees become more systemoriented. In recent years, the odd party out has been the True Path Party (Dogru Yol Partisi-DYP).

The Democratic Left Party (Demokratik Sol Parti-DSP) came to adopt a moderate stance on Islam. The party leader, Bülent Ecevit, has prevented ideological groups joining the party, and has also shunned clientelism and political patronage. Since 1999, Ecevit, as Prime Minister, led the most internally harmonious coalition government Turkey has ever had. Ecevit had always been a man of integrity. The (old) Republican People's Party he had led bordered being an anti-system party with its leftist rhetoric. His present political party (DSP) has a more balanced approach to politics. The DSP tries to blend social democracy with moderate nationalism. On Islam, Prime Minister Ecevit's ideas are somewhat different from those of the military and he makes them known. For instance, unlike the military, Ecevit thinks that religious groups such as Fethullaç1lar - one arm of the Disciples of Light (Nurcular) Movement led by Fethullah Gülen - does not pose a threat to the Republic and, in fact, Gülen may play a galvanizing role vis-à-vis the secularists and Islamists. However, Ecevit's stance is not openly confrontational.

Under Devlet Bahçeli the Nationalist Action Party (Milliyetçi Hareket Partisi-MHP) left behind its anti-capitalist, anti-West orientation, and took effective steps to cleanse itself of its militant youth group-Idealist Hearths (Ülkü Ocakları) - as well as its Islamist-nationalists- that have 
formed a separate party of their own - the Grand Union Party (Büyük Türkiye Partisi-BTP). The MHP is responsive to the religious and cultural sensitivities of the people; unlike the military, the party's view is that women university students should be able to attend universities with their headscarf, if they so choose. Yet the party does not press the issue, instead hoping that time will persuade the military in this regard. The MHP does not think that those women deputies of the party who cover their head should try to enter parliament with a headscarf. From 1980 to the present, particularly during recent years, the MHP has shed its ultra-nationalism and moved to the center of the political spectrum. Not unlike Ecevit, the MHP leader Bahçeli has impeccable personal characteristics; he values harmony in government and believes that the country's interests should be the party's primary concern. Like Ecevit, Bahçeli played a significant role for the harmony in the post-1999 coalition government, in which he was Deputy Prime Minister. There is a tension between Bahçeli and ANAP leader Mesut Y1lmaz, who is also a deputy prime minister; however, Bahçeli and Y1lmaz, with some help from Ecevit, do not allow it to escalate to crisis proportions.

In the 1980s, the Motherland Party (Anavatan Partisi-ANAP), under its then leader Turgut Özal, tried to represent four strands of thought-conservatism, economic liberalism, social democracy, and nationalism - and underlined the need for a synthesis of liberal economic rationality with social unity based on religious-moral values. The party stood for three freedoms - of conscience, expression, and entrepreneurship. It is true that today's ANAP, under the leadership of Mesut Y1lmaz, does not have a clearly anchored identity and failed to adapt to the changing cultural and political circumstances. Yet, the party successfully holds together economic liberals and nationalists, and has a strong proWestern stance. Y1lmaz also contributed to the post-1999 coalition government, although he is prone to pronouncing statements offensive to the military. Also, in the eyes of many, his personal characteristics are not as impeccable as those of Ecevit and Bahçeli.

The original rationale behind the formation of the post-1969 religiously-oriented political parties in Turkey did not evince anti-system characteristics. The goal was to foster moral development based upon religious values, not to establish a state based on Islam. However, Necmettin Erbakan failed to suppress disparate pro-political Islam voices in these parties and, consequently, they were closed one after another. Yet, during this long saga the notion of secularism cherished by these political parties underwent an important evolution. While earlier, secularism and 
Islam were seen as incompatible, more recently it was only demanded that the state and Islam should not interfere in each other's affairs. Furthermore, the latest of the religiously-oriented political parties in Turkey - the Justice and Development Party (Adalet ve Kalkınma Partisi-AKP) led by Recep Tayyip Erdoğan — is resolved not to use even religious symbols in politics.

Tansu Çiller's True Path Party has greatly suffered from its leader's personal characteristics and her conduct in politics. The party's misfortune was substantial because Çiller adopted a personal rule. Therefore it would not be inappropriate to talk about the DYP and Çiller interchangeably. It is true that Bülent Ecevit and his wife Rahșan Ecevit also had close control over the DSP; yet in the Ecevits' case, the close control they exercised was informed by certain principles, one of them being keeping the radical leftists out of the party. In the case of Çiller, there were no principles to speak of. Bahçeli gave first priority to the country, second to the party, and third to his own political fortunes. For Çiller, only her personal interests were important, nothing else mattered. She therefore resorted to political patronage and clientelism in the most unscrupulous manner. Also, as she had no principles, she was inconsistent, did not keep promises, and often adopted diametrically opposed views and policies in very short order. For instance, while in power, she in effect transferred the government's decisionmaking prerogatives on the Kurdish issue to the military; however, immediately after falling from power she exchanged harsh words with the military. Not only was Çiller devoid of any principles, but her personal integrity also was always in doubt.

Until recently, the (new) Republican People's Party (Cumhuriyet Halk Partisi-CHP), under Deniz Baykal, was ridden with factional politics. In addition, the party was too rigidly secularist, equating religion with irrationality and, therefore, overlooking the fact that Islam was an important sociological reality for the people in Turkey. This led to elitist tendencies in the party. Furthermore, the CHP discourse focused on the Republican principles and, consequently, the party was unable to come up with policies in other areas and in harmony with the requirements of changing times. However, lately there have been signs that the CHP intends to adopt a brand new orientation. The party's current aim is to overcome the state-society dichotomy. Baykal's new discourse of "Anatolian Left" not only calls for tolerance towards, but also appreciation of, religious piety. The CHP is also for the deepening of democracy in Turkey; it defends the rights of minorities as well as such traditionally oppressed groups as women. On the socio-economic front, the CHP on the 
one hand accepts the reality of market, though with some reservations and, on the other hand, it underlines the universal rules of social democracy. Its discourse is now human- rather than class-centered.

Turning finally to the ethnically-oriented political parties, the antisystem characteristics increased from HEP to DEP, but decreased from DEP to the People's Democracy Party (HADEP). Initially, HADEP too manifested an ethnically-oriented approach to politics. However, after 1999, following the Constitutional Court's allowing the party to compete at the national elections held in that year, the party leaders began to act in a more responsible manner, even asking for the public authorities' help in keeping their radical elements at bay. They now openly declare that theirs is a "Turkey-party."

While six of the seven parties considered in this volume have recently undergone different types of transformation that would facilitate the consolidation of democracy in Turkey in the foreseeable future, as noted, their recent record in terms of democratization in general and intra-party democracy in particular has not been promising. None of the seven parties have shown a willingness to allow socio-economic groups to play a role in the public decisionmaking process. Only the CHP worked in tandem with social groups, but those were identity groups, and not socio-economic groups. Furthermore, not all parties have paid attention to the sensitivities of the people on key issues like Islam and the need for a basic harmony in the polity and society. Exceptions here were the Democratic Left Party (DSP), the Nationalist Action Party (MHP), and the religiously-oriented parties. Not unexpectedly, the religiously-oriented parties tried to take into account the wishes and aspirations of the people with regard to Islam, but remained oblivious to the people's wish to see a basic harmony in the polity and society.

Intra-party democracy did not exist in any of the parties examined. Leaders dominated all of the parties, and were intolerant, of not only dissent, but also of constructive criticism. The one party that presented a semblance of intra-party democracy was ANAP, with its democratic centralism. Y1lmaz took others' advice, but his decisions were final; anybody who did challenge the leader would have found him/herself out in the wilderness. The True Path Party stood at the other end of the continuum, and was expected to promote only the personal political fortunes of the leader. In such political parties as the DSP, MHP, and the religiously- and ethnically-oriented parties, to a large extent leaders acted in accordance with certain ideals. In such parties as ANAP and the CHP, references were made to certain goals, but the leaders did not inspire 
confidence. In the True Path Party, there was neither an ideal nor confidence in the leader.

As a final note it may be suggested that the lack of intra-party democracy in some political parties lead to increased mainstream tendencies in those parties, but this was not the case in others. As examples of the political parties where leader domination was functional (as far as the present problematic is concerned), one can cite the DSP, MHP, CHP, HADEP, and the new Justice and Development Party (AKP). In DSP and AKP, the leaders leant their weight early in the game, and injected systemoriented characteristics into their parties. In the MHP and CHP, the leaders tried hard to remove anti-system characteristics from their parties, and were to a great extent successful. In HADEP, the leader seems to have made an effort similar to the MHP and CHP leaders'. However, the extent to which he has been successful is an open question. In the religiouslyoriented parties from the National Order Party to the Welfare Party, the leader Erbakan did not even try to make such an effort because he was afraid of losing the support of the radical Islamists. ANAP's leader Yllmaz's record is mixed: he was not strong enough to engender significant changes in his party and his own views did not clash with those of the establishment, however, the establishment was alienated from him to some extent because of his personality traits and his political conduct. Çiller was the worst case; she turned the party he had inherited from Süleyman Demirel into a "pariah."

Turkey's experience with democracy has been one of considerable progress towards the consolidation of democracy in the absence of a diffusion of democratic values among the political elite. The progress towards the consolidation of democracy has been a consequence of the fact that democracy was perceived as an end rather than as a means. When Turkey faced political legitimacy crises, democracy was not seen as the guilty party; rather, the blame was heaped upon politicians. In turn, the failure in the diffusion of democratic values has been an upshot of the fact that the state-centered political regime was replaced not by a civil-society-centered political regime, but by a polity-centered one. Turkey did not make a transition to democracy because social groups came to have increasing political efficacy and asked for a more open regime. The decision to make the transition to democracy was taken by the political elite themselves who have, however, shown reluctance to democratize themselves. 